\title{
ANALISIS MODEL IMPOR SUSU DI INDONESIA PERIODE TAHUN 2000 - 2016
}

\author{
Pebma Riska*, Pahantus Maruli**, Firmansyah** \\ *Alumni Magister Ilmu Peternakan Universitas Jambi \\ ** Program Studi Magister Ilmu Peternakan Universitas Jambi \\ Email :pebmariska@gmail.com
}

\begin{abstract}
ABSTRAK
Tujuan dari penelitian ini adalah menganalsis model produksi susu, konsumsi susu, harga susu dan impor susu beserta faktor-faktor yang mempengaruhinya. Penelitian ini menggunakan analisis data sekunder denganjenis data yang digunakan adalah data berurut waktu (time series) periode tahun 2000-2016. Dalam penelitian ini digunakan model persamaan produksi susu, konsumsi susu, harga susu dan impor susu. Proses analisis data dimulai dengan identifikasi model menggunakan uji order condition dan uji rank condition, uji asumsi klasik, analisis regresi 2SLS (two stage least square), uji validasi model dengan Theil's Inequality Coefficient (U-Theil).Hasil estimasi model produksi susu dipengaruhi oleh susu dan populasi penduduk mempengaruhi model konsumsi susu, untuk model harga susu variabel yang berpengaruh adalah pendapatan perkapita dan nilai tukar, selanjutnya model impor susu dipengaruh oleh variabel konsumsi susu dan harga susu impor. Kesimpulan dari penelitian ini adalah model produksi susu, konsumsi susu, harga susu dan impor susu dinyatakan signifikan dan berpengaruh.
\end{abstract}

Kata kunci: Impor, Produksi, Konsumsi dan Susu

PENDAHULUAN

Produksi susu Indonesia hanya tumbuh kurang dari $2 \%$ per tahun (Direktorat Budidaya Ternak Ruminansia, 2010). Produksi susu segar Indonesia sepanjang 2017 hanya tumbuh $0,81 \%$ menjadi 920 ribu ton dari tahun sebelumnya 912 ribu ton. Populasi sapi perah yang hanya mengandalkan kelahiran alami menjadi salah satu penyebab produksi susu nasional hanya tumbuh tipis. Pertumbuhan populasi sapi perah belum mampu mengimbangi pertumbuhan konsumsi. Berdasarkan sensus ternak tahun 2011 populasi sapi perah di Indonesia berjumlah 597.000 ekor, hanya mampu menghasilkan produksi susu berjumlah 900 ribu ton per tahun, sedangkan permintaan susu dalam negeri mencapai angka 3.461.538 ton, berarti produksi susu lokal di Indonesia hanya mampu mencukupi sekitar $26 \%$ permintaan konsumsi masyarakat Indonesia, sisanya sekitar $74 \%$ permintaan susu di Indonesia dicukupi oleh susu impor

Disamping permintaan susu yang semakin meningkat, berbagai faktor, baik faktor eksternal maupun faktor 
internal, menyebabkan impor susu semakin tinggi. Dari sisi eksternal, tuntutan IMF dalam paket reformasi termasuk penghapusan kebijakan rasio atau Bukti Serap (BUSEP) yang kemudian direalisasikan melalui Inpres No 4/1998 tentang Koordinasi Pembinaan dan Pengembangan Persusuan Nasional, komitmen penurunan tarif impor (GATT/ WTO, FTA regional dan bilateral) secara konsisten dan berkesinambungan serta jargonisasi white revolution oleh negara-negara eksportir susu dunia, telah mendorong meningkatnya impor dan penggunaan susu bubuk oleh Industri Pengolahan Susu (IPS) (Boediyana, 2008).

Kesenjangan antara pertumbuhan konsumsi dengan produksi susu menyebabkan jumlah impor susu Indonesia terus meningkat. Bila kondisi ini tidak diwaspadai, kesenjangan tersebut dapat menyebabkan kemandirian dan kedaulatan pangan (food soverignty) khususnya susu semakin jauh dari harapan, yang pada gilirannya berpotensi masuk dalam food trap negara eksportir. Artinya pemenuhan asupan nutrisi dari susu sangat tergantung dari kondisi pasar negara eksportir.

\section{METODE PENELITIAN}

\section{Jenis dan Sumber Data}

Jenis data yang akan digunakan dalam penelitian ini adalah data berurut waktu (time series) periode tahun 2000 2016. Time series merupakan serangkaian data pengamatan yang berasal dari satu sumber tetap dan terjadi berdasarkan indeks waktu $\mathrm{t}$ secara beruntun dengan interval waktu yang tetap (Cryer, 1986). Secara umum terdapat empat macam pola data time series yaitu horizontal, trend, musiman, dan siklis (Hanke dan Wichren, 2005).

\section{Model Persamaan Produksi Susu}

Model persamaan untuk produksi susu Indonesia ditulis sebagai berikut :

ProdSus $=\alpha_{0}+\alpha_{1}$ HarSus $_{\mathrm{t}}+\alpha_{2}$ KonSus $+\alpha_{3}$ PopSP $+\alpha_{4}$ ImporSus $_{\mathrm{t}}+\mathrm{U}_{1}$

Tanda parameter estimasi yang diharapkan (hipotesis) adalah sebagai berikut :

$\alpha_{1}, \alpha_{2}, \alpha_{3}>0 ; \alpha_{4}<0$

Dimana :

ProdSus $=$ Produksi susu Indonesia (Ton)

HarSus = Harga susu nasional (Rp/liter)

KonSus $=$ Konsumsi susu nasional (liter/kapita)

PopSP = Populasi sapi perah nasional (Ekor)

ImporSus $=$ Impor susu (Ton)

$\mathrm{U}_{1} \quad=$ Peubah pengganggu

\section{Model Persamaan Konsumsi Susu}

Setiadi (2003) menyatakan bahwa, keputusan pembelian dari 
pembeli sangat dipengaruhi oleh faktor kebudayaan, sosial, pribadi, dan psikologi dari pembeli. Sebagian besar adalah faktor-faktor yang tidak dapat dikendalikan oleh pemasar, tetapi harus benar-benar diperhitungkan. Faktorfaktor yang mempengaruhi konsumsi susu nasional tersebut dirumuskan dengan persamaan sebagai berikut :

KonSus $_{\mathrm{t}}=\beta_{0}+\beta_{1}$ ProdSus $+\beta$ ${ }_{2}$ ImporSus $+\beta_{3}$ Penduduk $+\beta$ ${ }_{4}$ HarSus $+\beta{ }_{5}$ Pendapatan $+\mathrm{U}_{2}$

Tanda parameter dugaan yang diharapkan (hipotesis) adalah sebagai berikut :

$\beta_{1}, \beta_{2}, \beta_{3}, \beta_{5}>0 ; \beta_{4}<0$

Dimana :

KonSus $=$ Konsumsi susu nasional (liter/kapita)

ProdSus = Produksi susu nasional (Ton)

ImporSus = Impor susu (Ton)

Penduduk = Jumlah penduduk (Jiwa)

HarSus = Harga susu nasional (Rp/liter)

Pendapatan = Pendapatan perkapita (US \$)

$\mathrm{U}_{2} \quad=$ Peubah pengganggu

\section{Model Persamaan Harga Susu}

Adapun model persamaan untuk harga susu nasional pada penelitian ini dapat ditulis sebagai berikut :

$$
\begin{aligned}
\text { HarSus }= & €_{0}+€_{1} \text { ProdSus }+€_{2} \text { KonSus } \\
& +€_{3} \text { ImporSus }+€_{4} \text { Pendapatan } \\
& +€_{5} \mathrm{NT}+\mathrm{U}_{3}
\end{aligned}
$$

Tanda parameter dugaan yang diharapkan (hipotesis) adalah sebagai berikut :

$€_{2}, €_{4}>0 ; €_{1}, €_{3,} €_{5}<0$
Dimana :

$\begin{array}{ll}\text { HarSus } & =\text { Harga susu nasional } \\ & \begin{array}{l}\text { (Rp/liter) } \\ \text { ProdSus }\end{array} \\ & \begin{array}{l}\text { (Ton) } \\ \text { (Toksi susu nasional }\end{array} \\ \text { KonSus } & =\text { Konsumsi susu nasional } \\ & \text { (liter/kapita) } \\ \text { ImpSus } & =\text { Impor susu (Ton) } \\ \text { Pendapatan } & =\text { Pendapatan perkapita } \\ & \text { (US \$) } \\ \text { NT } & =\text { Nilai Tukar Rupiah (Rp } \\ & \text { terhadap US \$) } \\ \mathrm{U}_{3} & =\text { Peubah pengganggu }\end{array}$

\section{Model Persamaan Impor Susu}

Permintaan impor suatu negara terjadi apabila jumlah barang yang diminta oleh konsumen domestik melebihi kapasitas jumlah barang yang ditawarkan produsendomestik pada harga tertentu (Koo dan Kennedy, 2005).Faktor-faktor yang mempengaruhi impor susu dirumuskan sebagai berikut :

$$
\begin{aligned}
\text { ImpSus } & =£_{0}+£_{1} \text { ProdSus }+£_{2} \text { KonSus } \\
& +£_{3} \text { HarSusIm }_{t}+£_{4} N T+ \\
& £_{5} \text { Tarif }_{t}+U_{4}
\end{aligned}
$$

Tanda parameter dugaan yang diharapkan (hipotesis) adalah sebagai berikut :

$£_{2}, £_{s}>0 ; £_{1}, £_{3}, £_{3}<0$

Dimana :

$$
\begin{array}{ll}
\text { ImpSus } & =\text { Impor susu (Ton) } \\
\text { ProdSus } & =\text { Produksi susu nasional } \\
& \text { (Ton) } \\
\text { KonSus } & =\text { Konsumsi susu nasional } \\
& \text { (liter/kapita) } \\
\text { HarSusIm } & =\text { Harga susu impor (US } \\
& \text { \$/Ton) } \\
\text { NT } \quad \begin{array}{l}
\text { Nilai Tukar Rupiah (Rp } \\
\text { terhadap US } \$)
\end{array} \\
\text { Tarif } \mathrm{f}_{\mathrm{t}} \quad=\text { Tarif impor }(\%)
\end{array}
$$


$\mathrm{U}_{4} \quad=$ Peubah penggangu

\section{HASIL DAN PEMBAHASAN}

\section{Perkembangan Populasi Sapi Perah}

Populasi sapi perah cukup berfluktuasi dalam kurun waktu 16 tahun terakhir, seperti yang terlihat pada Gambar 1. Rata-rata pertumbuhan populasi sapi perah Indonesia di
Indonesia periode tahun 2000-2016 adalah $3,21 \%$ per tahun. Pertumbuhan populasi sapi Indonesia yang paling besar terjadi pada tahun 2008 yaitu tumbuh sebesar 22,32\%. Kemudian pada tahun 2013, pertumbuhan populasi sapi perah Indonesia mengalami kondisi terburuk yaitu berada diangka $-27,40 \%$.

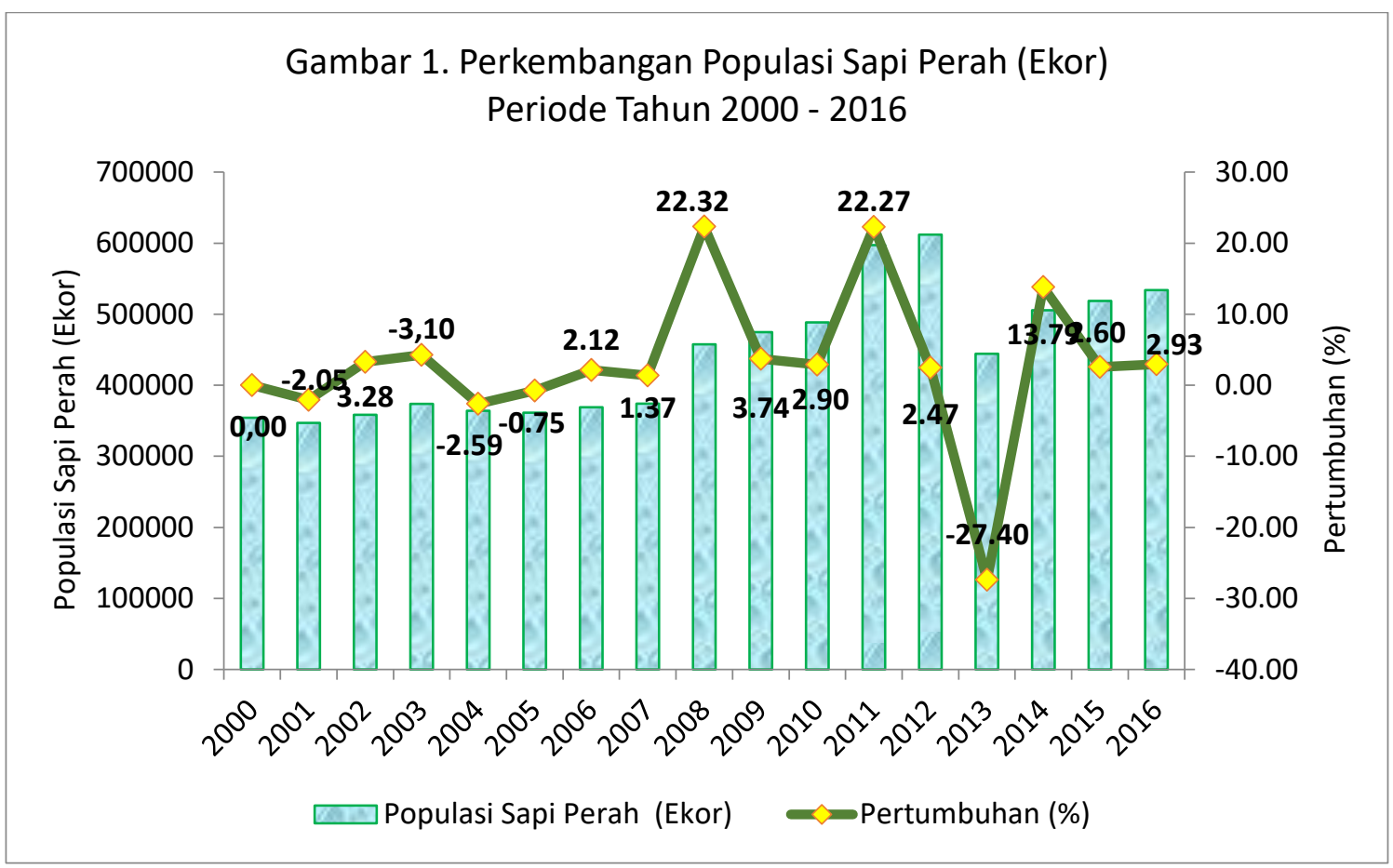

Sumber : Direktorat Jendral Peternakan dan Kesehatan Hewan

Perkembangan Produksi Susu

Produksi susu Indonesia pada tahun 2000 sebanyak 479.598 ton dan terus meningkat selama 5 tahun hingga tahun 2005 menjadi 614.113 ton. Tetapi pada tahun 2006 hingga 2008 mengalami penurunan menjadi 474.439 ton. Kemudian Pada tahun 2010 dan 2011 mengalami kenaikan yang sangat segnifikan menjadi 974.694 ton dan 2 tahun berikutnya mengalami penurunan pada tahun 2012 dan 2013 menjadi 786.871 ton. Namun, pada tahun 2014 hingga 2016 mengalami lagi peningkatan meski hanya sedikit yaitu kembali berfluktuasi sebesar 852.951 ton. 
Pertumbuhan produksi susu Indonesia yang tertinggi pada tahun 2010 yaitu tumbuh sebesar $86,15 \%$ dari tahun 2009. Namun, pada tahun 2007 terjadi penurunan pertumbuhan sebesar $-19,48 \%$ dibandingkan tahun 2006. Rata-rata pertumbuhan produksi susu Indonesia periode tahun 2000-2016 yaitu sebesar $5,51 \%$ per tahun.

\section{Perkembangan Konsumsi Susu}

Perkembangan konsumsi susu perkapita Indonesia naik dan turun selama 16 tahun, yang dapat dilihat pada Gambar 2. Pada tahun 2000 hingga 2002 sebanyak 0,21 Liter/kapita kemudian mengalami penurunan pada tahun 2003 hingga tahun 2005 menjadi 0,10 liter/kapita. Pada tahun 2006 hingga tahun 2008 konsumsi susu mulai meningkat menjadi 0,21 liter/perkapita, dan dua tahun kemudian mengalami penurunan tahun 2009 dan tahun 2010 yaitu menjadi 0,10 liter/kapita. Tahun 2011 dan 2012 mengalami sedikit peningkatan menjadi 0,16 liter/kapita. Dan pada tahun 2013 hingga tahun 2016 terjadi fluktuasi ditiap tahun nya dari 0,1 liter/kapita hingga 0,16 liter/kapita.

Pertumbuhan tertinggi pada konsumsi susu perkapita Indonesia terjadi pada tahun 2006 yaitu tumbuh sebesar $60 \%$ dari tahun sebelumnya. Kemudian pada tahun 2013 penurunan pertumbuhan cukup besar yaitu sebesar $-37,50 \%$. Dari fluktuasi data di atas maka dapat diketahui rata-rata pertumbuhan dari konsumsi susu perkapita Indonesia yaitu $3,78 \%$ per tahun. 


\section{Gambar 2. Perkembangan Konsumsi Susu Indonesial}

Periode Tahun 2000 - 2016

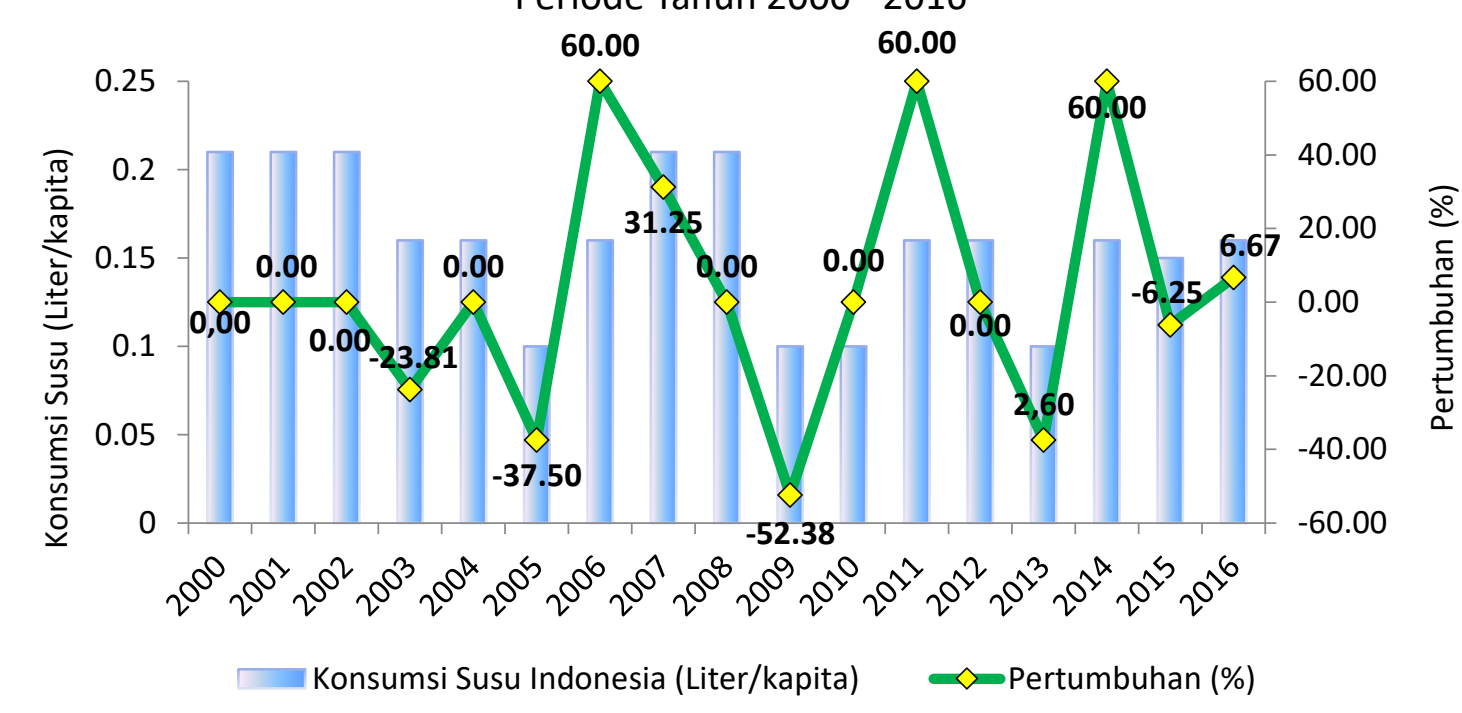

Sumber : Kementerian Pertanian Republik Indonesia

\section{Perkembangan Harga Susu}

Fluktuasi perkembangan harga susu Indonesia tersaji pada Gambar 3. Pada tahun 2000 sebanyak Rp.2.450 per $\mathrm{kg}$ kemudian terus meningkat pada tahun 2001 hingga tahun 2015 menjadi Rp.8.919 per kg. Akan tetapi pada tahun 2016 harga susu mengalami sedikit penurunan menjadi Rp.7.500 per kg. Pertumbuhan harga susu Indonesia pada tahun 2004 mengalami peningkatan paling tinggi selama periode tahun 2000-2016 yaitu sebesar 38,83\% pada tahun 2014 dan pertumbuhan harga susu Indonesia periode tahun 2000-2016 mengalami penurunan terendah pada tahun 2016 menjadi sebesar -15,91\%. Adapun rata-rata pertumbuhan untuk harga susu Indonesia periode tahun 2000-2016 yaitu 7,94\%.

Dari sisi internal, sebagian besar (90\%) produsen Susu Segar Dalam Negeri (SSDN) merupakan peternak rakyat. Kemampuan produksi mereka masih rendah, harganya relatif lebih mahal, sehingga tidak bisa bersaing dengan susu bubuk impor. Untuk meningkatkan produksinya, peternak sapi perah rakyat menghadapi berbagai permasalahan, seperti skala usaha ternak yang relatif kecil, kemampuan induk untuk memproduksi susu belum optimal, serta kemampuan penanganan ternak dan produk susu segar yang relatif rendah (Boediyana, 2008). 


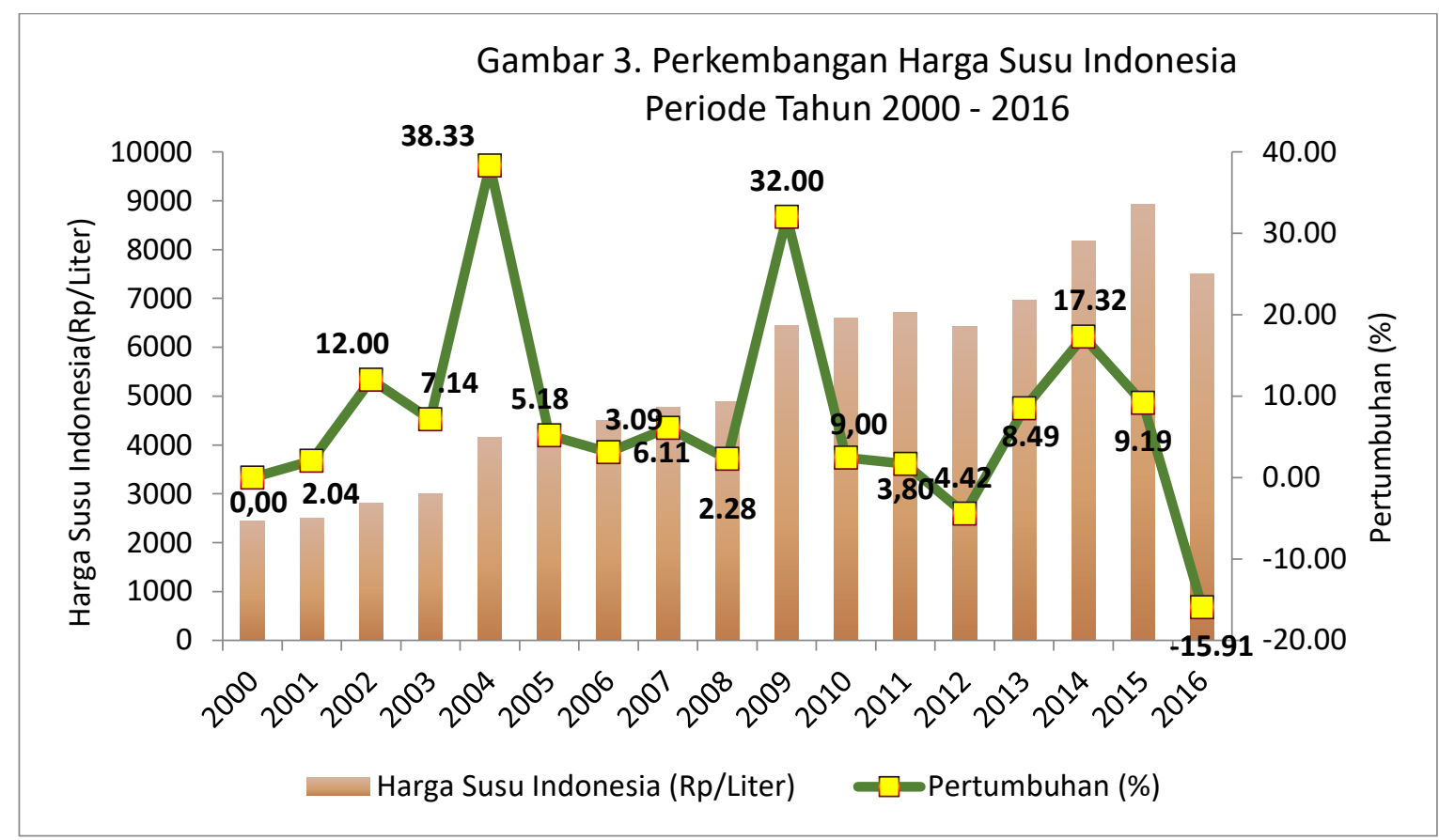

Sumber : Kementerian Pertanian Republik Indonesia

Perkembangan Impor Susu

Kesenjangan antara pertumbuhan

konsumsi dengan produksi susu menyebabkan jumlah impor susu Indonesia terus meningkat. Bila kondisi ini tidak diwaspadai, kesenjangan tersebut dapat menyebabkan kemandirian dan kedaulatan pangan (food soverignty) khususnya susu semakin jauh dari harapan, yang pada gilirannya berpotensi masuk dalam food trap negara eksportir. Artinya pemenuhan asupan nutrisi dari susu sangat tergantung dari kondisi pasar negara eksportir (Nguguyen, 2010). 


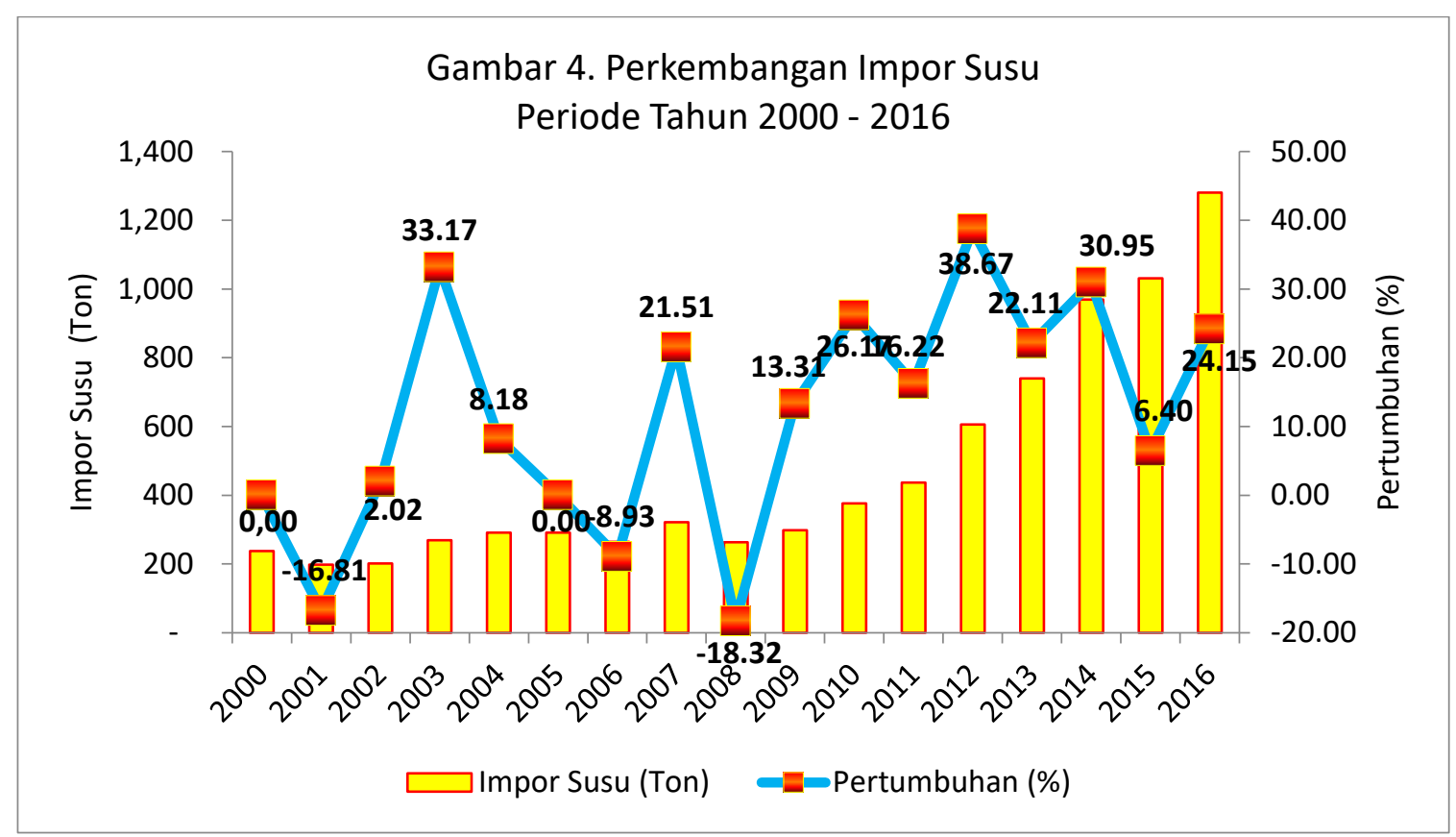

Sumber : Kementerian Pertanian Republik Indonesia

Kegiatan impor susu yang dilakukan Indonesia meningkat sangat besar selama periode 2000-2016 seperti yang tersaji pada Gambar 4. sehingga, terbukti adanya bahwa impor susu pada tahun 2000 sebanyak 238 ton kemudian menurun pada tahun 2001 menjadi 198 ton. Pada tahun 2002 hingga tahun 2007 mengalami peningkatan impor susu Indonesia menjadi 322 ton dan pada tahun 2006 mengalami penutunan menjadi 298 ton. Tetapi, pada tahun 2007 hingga 2016 impor susu indonesia selalu naik dari tahun sebelumnya menjadi sebesar 1.280 ton. Pada tahun 2012 menjadi tahun pertumbuhan terbesar impor susu Indonesia yang tumbuh sebesar 38,67\%. Tetapi, pada tahun 2008 menjadi tahun dimana penurunan pertumbuhan untuk impor susu yaitu sebesar $-18,32 \%$. Maka nilai rata-rata pertumbuhan impor susu di Indonesia selama 21 tahun yaitu 12,42\% per tahun.

Impor susu pada jangka pendek dipengaruhi secara siginifikan oleh produksi susu domestik, harga riil susu impor lag pertama, pendapatan perkapita lag ketiga dan nilai tukar riil Rupiah pada lag kedua dengan pengaruh yang bersifat negatif. Pendapatan perkapita secara serta dummy penghapusan kebijakan rasio impor secara signifikan dan positif mempengaruhi impor susu. Penghapusan kebijakan rasio diterapkan pada waktu yang relatif bersamaan dengan krisis ekonomi 1997, oleh 
karena itu efek netto peningkatan impor susu yang terjadi relatif kecil dalam jangka pendek. Harga riil susu domestik tidak berpengaruh terhadap impor susu karena bargaining position GKSI masih lemah dalam negosiasi penetapan harga dengan IPS (Boonsaeng, 2006).

Penelitian yang dilakukan Budiyono (2018) dalam penelitiannya yang berjudul Analisis Harga Impor dan Ekspor susu bahwa Kenaikan harga bahan baku susu di pasar Indonesia merupakan momentum penting yang mengisyaratkan betapa perlunya memelihara ketahanan produksi susu dalam negeri, karena selama kurun waktu itu susu segar dalam negeri dapat menjadi "buffer" yang dapat menyanggah kebutuhan bahan baku susu bagi IPS, dengan terjadinya penurunan "supply" susu di pasar Indonesia.

\section{Perkembangan Harga Susu Impor}

Pada perkembangan harga susu impor terus mengalami fluktuasi dimulai dari tahun 2000 ke tahun 2001 mengalami kenaikan dari 1.613,17 US\$/Ton menjadi 2.066,99 US\$/Ton tetapi pada tahun berikutnya mengalami naik turun yang tidak stabil hingga ditahun 2005 saimpai 2008 sedikit terjadi kestabilam dari 2.306,19 sampai 3676,28 US\$/Ton, dan pada tahun 2009 menurun menjadi 2691,42 US\$/Ton tahun 2010 hingga tahun 2011 mengalami kenaikan hingga 4.000,89 US\$/Ton, dan tahun selanjutnya mengalami penurunan hingga tahun 2016 menjadi 2.044,32US\$/Ton. Menurut Ilham (1998) dimana harga susu dunia berpengaruh positif terhadap harga susu impor. 


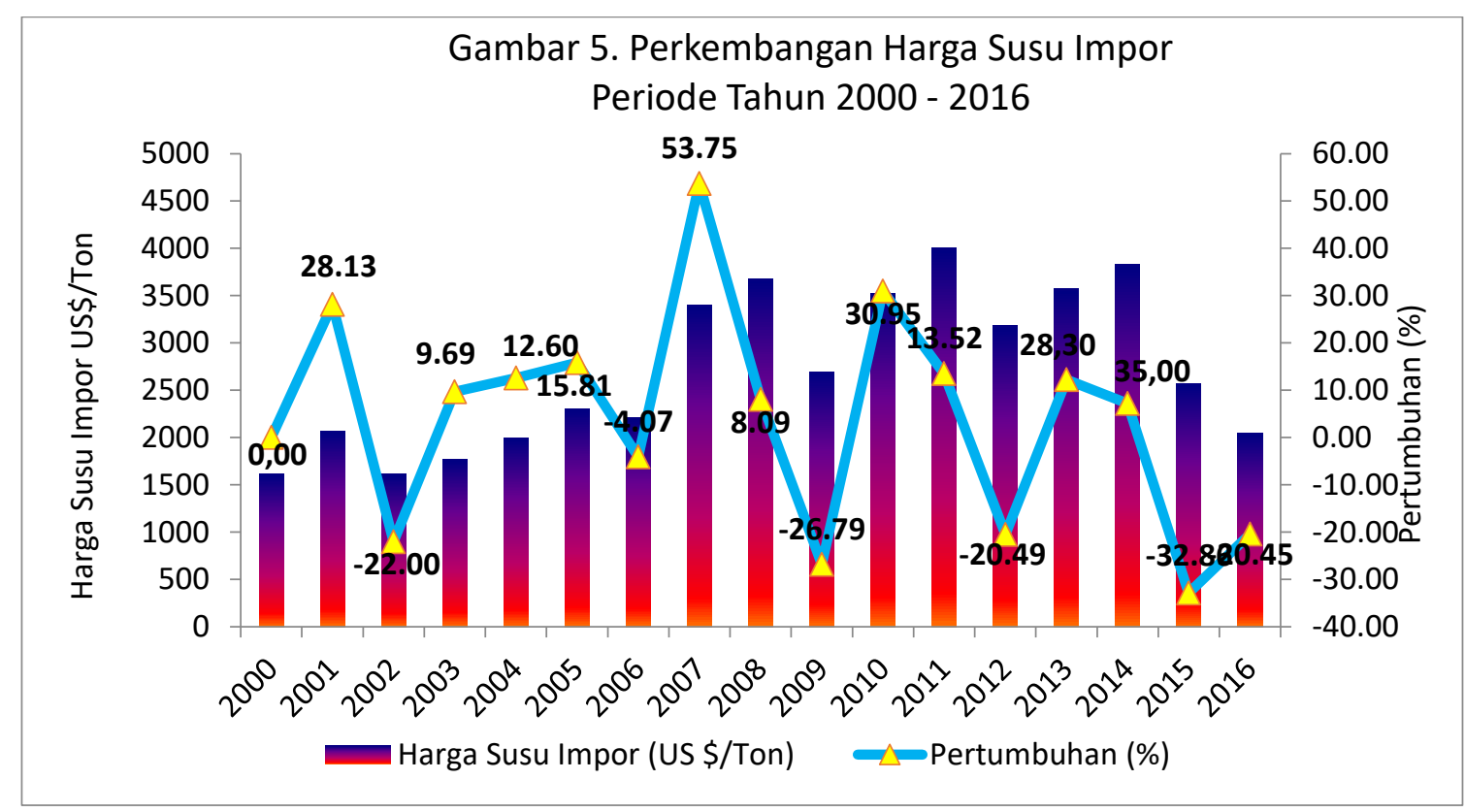

Sumber : Kementerian Pertanian Republik Indonesia

\section{Model Persamaan Produksi Susu Indonesia}

Berdasarkan hasil analisis simultan pada persamaan produksi susu Indonesia (ProdSus) maka diperoleh model persamaan sebagai berikut :

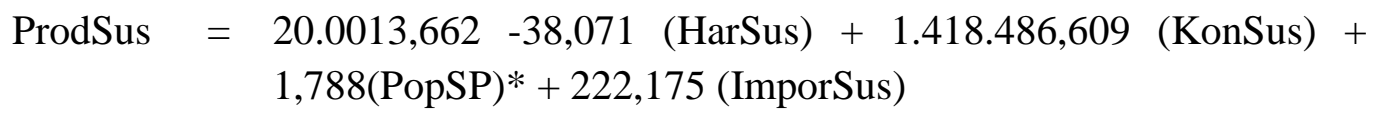

\section{Model Persamaan Konsumsi Susu Indonesia}

Dari hasil analisis simultan pada persamaan konsumsi susu Indonesia (KonSus) maka diperoleh model persamaan sebagai berikut :

$$
\begin{aligned}
\text { KonSus }= & 5,599+19,539 \text { (ProdSus })+18.205,522(\text { ImporSus }) \quad 2,864 \\
& \left.(\text { Penduduk })-4.868,343 \text { (HarSus)* })^{*}+27.401,923 \text { (Pendapatan }\right)
\end{aligned}
$$

\section{Model Persamaan Harga Susu Indonesia}

Dari hasil analisis simultan yang didapat pada persamaan harga susu Indonesia (HarSus) maka diperoleh model persamaan sebagai berikut :

$$
\begin{aligned}
\text { HarSus }= & -2.327,976+000(\text { ProdSus })+2,687 \text { (KonSus) }-2,185 \text { (ImporSus) } \\
& +1.034(\text { Pendapatan })^{*}+202(\text { NTR })
\end{aligned}
$$

\section{Model Persamaan Impor Susu (ImporSus)}

Berdasarkan hasil analisis simultan pada persamaan impor susu (ImporSus) maka diperoleh model persamaan sebagai berikut :

$$
\begin{aligned}
\text { ImporSus }= & -778,693-1.810(\text { ProdSus })+2.313(\text { KonSus })-0,156 \\
& (\text { HarSusIm })^{*}+0,111(\text { NTR })^{*}-61.030(\text { Tarif })
\end{aligned}
$$




\section{KESIMPULAN}

Penelitian ini menyimpulkan bahwa persamaan produksi susu Indonesia dipengaruhi oleh harga susu Indonesia, persamaan konsumsi susu nasional dipengaruhi oleh harga susu Indonesia dan jumlah penduduk, dan persamaan harga susu Indonesia dipengaruhi oleh pendapatan perkapita dan nilai tukar, serta persamaan impor susu dipengaruhi oleh konsumsi susu Indonesia dan harga susu impor.

\section{DAFTAR PUSTAKA}

Asima, R. S. P. 2012. Analisis Faktor Faktor yang Mempengaruhi Impor Daging Sapi di Indonesia. Economic DevelopmentAnalysis Journal. Vol 1 No 2. Hal : 1-14.

Boediyana, T. 2008. Menyosong Agribisnis Persusuan yang ProsPektif Di Tanah Air. Trobos. No. 108 September 2008 Tahun VII.

Boonsaeng, T. (2006). Three essays on the demand of imported and domestic meat and livestock in the United States.

Bruton, H. J. (1998). A reconsideration of import substitution. Journal of economic literature, 36(2), 903936

Cryer, J. D. 1986. Time Series Analysis. PWS Publishers. Boston.

Direktorat Jenderal Peternakan dan Kesehatan Hewan. 2013. StatistikPeternakan dan Kesehatan Hewan(Livestock and Animal HealthStatistics) 2012. Jakarta: Direktorat Jenderal
Peternakan dan Kesehatan Hewan Kementerian Pertanian Republik Indonesia

Direktorat Jenderal Peternakan. 2009. Blue Print Program Swasembada Daging Sapi. Kementerian Pertanian. Jakarta.

Hanke, J. E dan Wichren, D. W. 2005. Busines Forecasting. Pearson Education. New Jersey.

Jiuhardi. 2016. Kajian Tentang Impor Daging Sapi di Indonesia. Jurnal Forum Ekonomi. Vol 17 No 2. Hal : 75-91.

Koo, W. W. \& P. L.Kennedy. 2005. International Trade and Agriculture. Oxford: Blackwell Publishing, Second Edition. New York: Harper and Row Publishers Inc.

Kementerian Perdagangan RI. 2014. Statistik Harga Internasional 2008-2013. Diunduh tanggal 05 September 2014 dari http://www.kemendag. go.id/id/economic-profile/prices/ international-pricetable? year $=2013$.

Narayan, S. and Narayan, P. K. (2005) An empirical analysis of Fijiees import demandfunction. Journal of Economic Studies. Vol. 32, No. 2: $158-68$

Nguyen, G. V., \& Jolly, C. M. (2010, January). Seafood Import Demand in the Caribbean Region. In 2010 Annual Meeting, February 6-9, 2010, Orlando, Florida (No. 56479). Southern Agricultural Economics Association.

Setiadi, N.J. 2003. Perilaku Konsumen : Konsep dan Implikasi UntukStrategi dan Penelitian Pemasaran. Jakarta : Kencana. 